\title{
Expression Profile of Transcription Factor ELK-1 and ELK-1 Target Genes on Lymphoma-Leukemia Cell Lines
}

\author{
Hande AKALAN1, Duygu YASAR SIRIN*1 \\ ${ }^{1}$ Tekirdag Namik Kemal University, Faculty of Arts and Science, Department of Biology, 59030, Tekirdag
}

(Alınış / Received: 09.01.2018, Kabul / Accepted: 09.03.2018, Online Yayınlanma / Published Online: 16.04.2018)

\section{Keywords}

ELK-1,

ELK-1 Target Genes,

Expression profile

\begin{abstract}
Prognostic molecular markers identified in leukemia are becoming increasingly important especially in risk stratification and to determine therapy. In this study, we investigate the role of ELK-1 transcription factor and its potential target genes in four cell lines; Daudi, Jurkat, K-562 and HL-60. To evaluate ELK-1, MCPIP, MCL-1, BCL-10, CEBPB and SRF genes expression profiles we have performed a Real-time PCR analysis on Daudi, Jurkat, K-562 and HL-60 cell lines. ELK-1 over expression concomitant with SRF overexpression was detected only in Daudi cell line while only SRF overexpression was detected in jurkat cells. Expression of MCPIP, MCL-1, BCL-10 and CEBPB genes were decreased in all cell lines. Protein levels or phosphorylation status of ELK-1, BCL-10, CEBPB, MCL-1, MCPIP and SRF, moreover, changes that may occur when ELK-1 continuous overexpression is provided or completely silenced in these cell lines have not been evaluated. These questions are suggestions for future investigations.
\end{abstract}

\section{Lenfoma-Lösemi Hücre Hatlarında Transkripsiyon Faktörü ELK-1 ve ELK-1 Hedef Genlerinin Ekspresyon Profili}

\section{Anahtar Kelimeler} ELK-1,

ELK-1 Hedef Genler, Ekspresyon profili

\begin{abstract}
Özet: Lösemide yeni moleküler belirteçlerin tanımlanması prognostik risk saptanması ve tedavinin belirlenmesinde gittikçe önem kazanmaktadır. Bu çalışmada, ELK-1 transkripsiyon faktörü ve potansiyel hedef genlerinin rolü Daudi, Jurkat, K-562 ve HL-60 hücre hatlarında araștırılmıștır. ELK-1, MCPIP, MCL-1, BCL10, CEBPB ve SRF gen ekspresyon profillerini değerlendirmek için Daudi, Jurkat, K562 ve HL-60 hücre hatlarında Gerçek-Zamanlı PZR analizi yapılmıştır. Daudi hücre hattında ELK-1 aşırı ekspresyonuna eşlik eden SRF artışı ve Jurkat hücrelerinde ise sadece ELK-1 artışı saptanmıștır. MCPIP, MCL-1, BCL-10 ve CEBPB genlerinin ekspresyonunun tüm hücre hatlarında kontrol grubuna kıyasla daha düşük olduğu saptanmıștır. ELK-1, BCL-10, CEBPB, MCL-1, MCPIP ve SRF'nin protein seviyeleri veya fosforilasyon durumu, ayrıca ELK-1 sürekli aşırı ekspresyonu sağlandığında veya bu hücre hatlarında tamamen susturulduğunda meydana gelebilecek değişiklikler değerlendirilmemiştir. Bu sorular gelecekteki çalışmalar için önerilmektedir.
\end{abstract}

\section{Introduction}

Understanding the pathogenesis of and identification markers to diagnose leukemia is still the subject of many studies. Recurrent balanced structural rearrangements are very important in diagnosis and accepted as prognostic factors in acute myeloid leukemia (AML), acute lymphoblastic leukemia (ALL) and other hematologic malignancies [1]. However, some imbalanced chromosomal abnormalities, especially submicroscopic rearrangements, cannot be detected by conventional cytogenetics [2].
In our previous study, we have used oligo array Comparative Genomic Hybridization (oaCGH) to characterize chromosomal rearrangements in 41 acute leukemia samples. Along with many findings, one of the prominent one was the recurrent duplication of the ELK-1 oncogene which was observed in both ALL and AML cases. We have also reported deletion of CEBPB (CCAAT Enhancer Binding Protein-B) and duplication of serum response factor (SRF) in AML patients [3]. 
ELK-1, along with ELK-4 (SAP1) and ELK-3 (SAP2/Net), is a member of the ternary complex factor (TCF) subfamily of ETS-domain transcription factors which do not exhibit tissue specificity [4-6]. Ternary complex factors, with respect to the serum response, activate transcription of immediate-early genes (IEG) such as c-fos, egr-1, and nur77, and the muscle-specific genes; actin, myosin heavy chain and muscle creatine kinase. ELK-1 regulation of these genes is mediated by serum response elements (SREs) that bind SRF, a transcription factor that belongs to the MADS box family $[7,8]$ and can be activated by mitogen-activated protein (MAP) kinase phosphorylation $[9,10]$. An interruption in the MAPK signaling pathway has been reported by numerous studies in many cancer types including hematological malignancies $[11,12]$.

In addition to immediate growth response function of ELK-1, many studies are suggesting different roles, and /or ELK-1 might target a distinct subset of genes function in many developmental processes, from hematopoiesis to formation of functional neural circuits [4, 13]. CEBPB is a group of transcription factors that belong to the CREB superfamily, participating in a number of biologic responses, including energy metabolism, fat storage, tissue differentiation, hematopoiesis, the immune response, antibacterial defense, and female fertility [14, 15]. The CEBPB is a candidate ELK-1-interacting protein through the MAPK pathway that also plays a role in the suppression of myeloid and lymphoid leukemogenesis $[14,15]$.

As far as our knowledge is concerned, published data searching a role for ELK-1 in leukemia pathogenesis and /or prognosis are very limited. For this purpose, in this study we investigated whether there was a change in the expression of ELK-1, CEBPB and SRF genes. We have tried to answer these questions; Does ELK-1 gene amplification that we have detected using oaCGH, also means an increase in the mRNA transcription? If so, does ELK-1 increased expression affect SRF and CEBPB mRNA transcription on lymphoma-leukemia model cell lines? In this presented study, besides CEBPB and SRF small subset of possible candidate genes for ELK-1 transcription factor; MCPIP, Myeloid Cell Leukemia 1 (MCL-1) and B cell CLL/lymphoma 10 (BCL-10) genes expressions were evaluated.

MCPIP gene (also called the ZC3H12A gene), encodes MCPIP is an important regulator of inflammatory processes $[16,17]$. MCPIP1 is induced by Monocyte Chemoattractant Protein-1 (MCP-1) and Interleukin (IL-1) whose signals are transduced through the Nuclear Factor Kappa B (NFkB) and MAPK pathways $[17,18]$. The transcription factor ELK-1 plays an important role in the activation of MCPIP expression in response to IL-1b stimulation [19]. Previous studies have shown that as a response to cell differentiation and apoptosis-inducing stimuli of granulocyte / macrophage colony stimulating factor (GM-CSF) MCL-1 expression increases and induce cell differentiation HL-60, THP-1, U-937 and K562 cell lines [20]. A study by Boros, J. and colleagues found that the MCL-1 gene is associated with SRF and is one of the target genes of the ELK-1/SRF complex [5]. BCL-10 protein is an adaptor that activates the receptor-mediated apoptosis pathway and the NFkB survival pathway $[21,22]$. The role of BCL-10 in acute leukemia is less clear. However, ELK-1 has been shown to suppress the BCL-10 promoter [4] for this reason $B C L-10$ as one of the possible candidate genes has been included to the study.

\section{Material and Method}

\subsection{Control samples and cell lines}

Viable cell suspensions were obtained from peripheral blood samples of 24 healthy volunteers and used as control samples. The human leukemia cell lines Daudi, Jurkat, K-562, and HL-60 were obtained from American Type Culture Collection (ATCC, USA)

\subsection{Cell cultures}

Jurkat, Daudi, K-562, HL-60 cell lines were maintained in RPMI1640 (Sigma) medium supplemented with $10 \%$ fetal calf serum (Multicell), $1 \%$ L-glutamine (Multicell), $1 \%$ penicillinstreptomycin (Sigma) and 1\% amphotericin B (Multicell) in a humidified atmosphere with 5\% CO2 at $37^{\circ} \mathrm{C}$. Living cells were stained with trypan blue (Fluka) staining, and subsequent cells count was quantified with a Neubauer chamber (Marienfeld). RNA isolation was performed when the number of cells reached $5.3 \times 10^{6}$ cells/flask.

\subsection{RNA isolation, reverse transcriptase-PCR, and real time-PCR studies}

RNA isolation performed with PureLink RNA mini kit (Invitrogen) for cell lines and Miniblood RNA isolation kit (Qiagen) were used for blood samples. RNA from all samples was quantified by spectrometric analysis (Thermo Fisher Scientific Nanodrop products, DE, USA). cDNA was obtained using Applied High Capacity RT kit (Roche).

Gene expression levels of Elk-1, MCPIP, MCL-1, BCL10, CEBPB and SRF genes were determined with TaqMan probes (Applied Biosystems) using Applied Biosystems 7300/7500 Real-Time PCR System. For each gene, gene-specific custom assays were used (Elk-1 gene cat no: 4331182 ID: 2002, MCPIP gene cat no: 4331182 ID: 80149 , BCL-10 gene cat no: 4331182 ID: 8915, CEBPB gene cat no: 4331182 ID: 1051, SRF gene cat no: 4331182 ID: 6722 , the GAPDH gene cat no: 4331182 ID: 2539). Increase or decrease in gene expression was analyzed quantitatively using 
housekeeping gene Glyceraldehyde Phosphate Dehydrogenase (GAPDH).

\section{Results}

ELK-1, MCPIP, MCL-1, BCL-10, CEBPB and SRF genes expression were determined in Human leukemia cell lines Jurkat, K-562, HL-60 and lymphoma cell line Daudi. Relative Quantity (RQ) values were analyzed for each experimental group using 7500 Fast-SDS program. GAPDH was used as endogenous control and Control group accepted as reference sample (means that the expression of the gene of interest is $100 \%$ and so the $\mathrm{RQ}$ value is 1 [23]).

Graphical demonstration of Real-time PCR results for the four cell lines included in the study are given in Figure 1 and $\mathrm{RQ}$ values obtained from control group and cell lines are given in Table 1.

Gene expression of ELK-1 increased 20\% in Jurkat cell line (RQ: 1.20) and 203\% in Daudi cell line (RQ: 2.03). SRF gene expression increased $50 \%$ only in Daudi cell line (Daudi RQ: 1.50) when compared with control group. The expression of MCPIP, MCL-1, BCL10 and CEBPB genes decreased in all cell lines including ELK-1 overexpressing Jurkat and Daudi.

\section{Discussion and Conclusion}

ELK-1 is a member of ETS (E-twenty-six) oncogene superfamily transcription factor without tissue specificity [6]. ETS transcription factors are involved in regulation of cell differentiation, cell cycle control, cell migration, cell proliferation, apoptosis and angiogenesis [4, 6]. ELK-1 provides transcription of
Immediate Early Genes (IEG) that responds to growth factors [8].

Identification of different ELK-1 target genes aside from the IEG is a research topic for many studies. However, there are limited research exploring association between ELK-1 overexpression and haematological malignancies in the literature. We have performed our study in HL-60, Jurkat, Daudi and K-562 cell lines which are often used as a model for the investigation of hematological malignancies and determined the changes in gene expression of ELK-1. In addition, the expression levels of five genes (BCL10, CEBPB, MCL-1, MCPIP and SRF) that are possible targets for ELK-1 were also investigated in order to elucidate the role of ELK-1 in leukemogenesis.

Relative Quantification (RQ) was performed using the GAPDH as endogenous control and control group as a calibrator according to the average $\mathrm{Ct}$ values obtained. Fold difference in gene expression was calculated according to RQ values of GAPDH of the control group. In the Daudi cell line, the ELK-1 gene expression increased 2.03 fold and the SRF gene expression increased 1.50 fold. In the Jurkat cell line, only ELK-1 gene expression increased 1.20 fold (Table 1). There were no changes in the expression of ELK-1, SRF, MCPIP, MCL-1, BCL-10 or CEBPB genes in the other two cell lines. Both Daudi and Jurkat cells are lymphoblastic in the origin but, no change in ELK1 expression was detected in myeloblastic K-562 and HL-60 cells. In Daudi cell line, an increase in the gene expression of SRF involved in the ternary complex with ELK-1 transcription factor was observed. In the Jurkat cell line, the SRF gene was not affected by the increase in ELK-1.

RQ

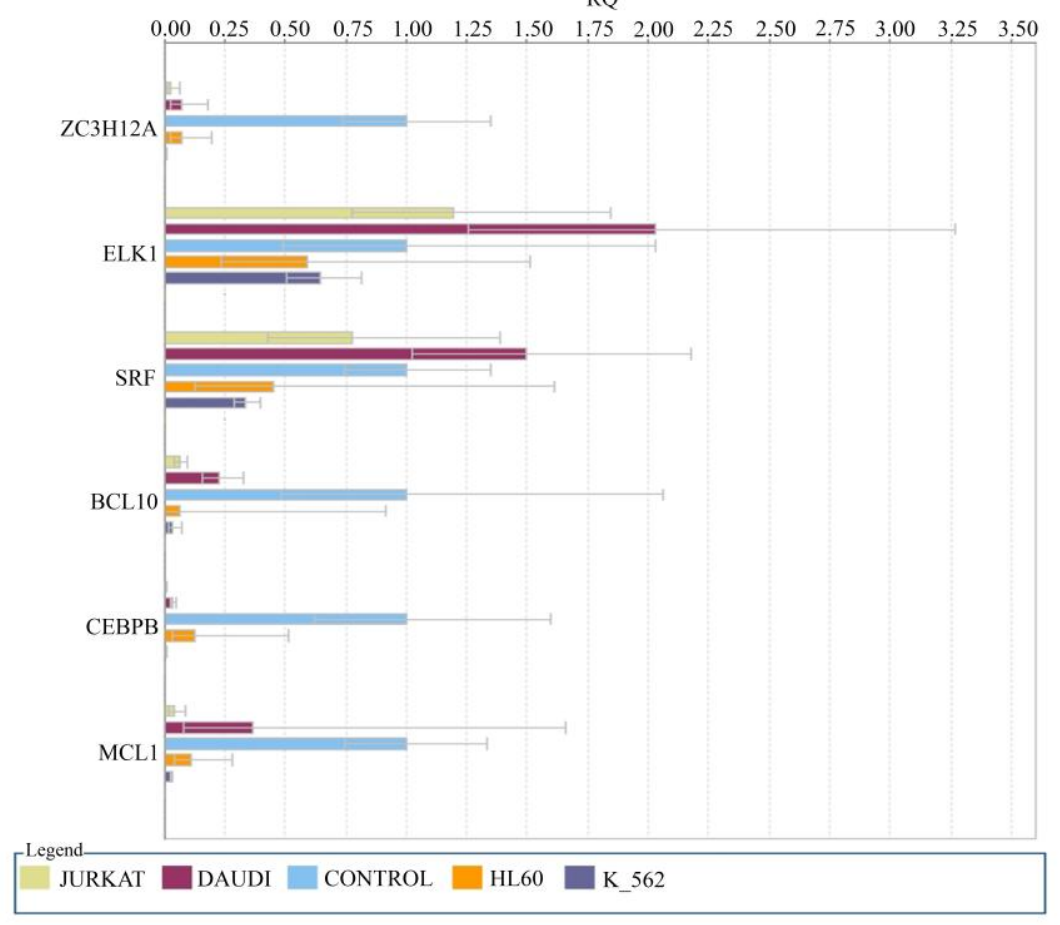

Figure 1. Graphical demonstration of Real-time PCR results 
Table 1. RQ values obtained from control group and cell lines

\begin{tabular}{ccccccccc}
\hline Sample & GAPDH & MCPIP & MCL-1 & ELK-1 & BCL-10 & CEBPB & SRF \\
\hline Control & 1 & 1 & 1 & 1 & 1 & 1 & 1 \\
K-562 & 1 & 0,01 & 0,03 & 0,64 & 0,03 & 0,01 & 0,34 \\
Jurkat & 1 & 0,03 & 0,04 & 1,20 & 0,06 & 0,01 & 0,78 \\
Daudi & 1 & 0,07 & 0,40 & 2,03 & 0,23 & 0,04 & 1,50 \\
HL-60 & 1 & 0,08 & 0,11 & 0,60 & 0,06 & 0,13 & 0,46 \\
\hline
\end{tabular}

CArG box located in the MCPIP gene promoter is a binding site for SRF. Furthermore ELK-1 binds to ETS domain of MCPIP gene and regulates gene expression [18]. However, in our study, it was observed that the increased expression of ELK-1 in Daudi and Jurkat cells did not cause a change in the MCPIP gene expression. A study by Boros J. et all showed that the MCL-1 gene is associated with SRF and is one of the target genes of the ELK-1/SRF complex [5]. However, in our study it was determined that increased expression of ELK-1 in Daudi and Jurkat cells did not cause an alteration in the MCL-1 gene expression.

The CEBP are a group of transcription factors that belong to the CREB superfamily, participating in a number of biologic responses, including energy metabolism, fat storage, tissue differentiation, hematopoiesis, the immune response, antibacterial defense, and female fertility $[14,15]$. Studies have shown that CEBPB plays a critical role in acute promyelocytic leukemia cell differentiation. The CEBPB protein is a candidate ELK-1 interacting protein through the MAPK pathway that also plays a role in the suppression of myeloid and lymphoid leukemogenesis $[14,15]$. However, in our study, it was determined that the expression of CEBPB did not change in Daudi and Jurkat cells, in which ELK-1 transcription was increased.

We haven't examined the changes in the protein levels or phosphorylation status of BCL-10, CEBPB, MCL-1, MCPIP and SRF. Moreover, changes that may occur when ELK-1 continuous overexpression is provided or completely silenced in these cell lines have not been evaluated. These questions are suggestions for future studies.

\section{Acknowledgment}

This study is supported by grants (Project no: NKUBAP.00.10.AR.12.08) from Namik Kemal University Scientific Research Administration Division.

\section{References}

[1] Walker A., Mrozek K., Kohlschmidt J., Rao K.W., Pettenati M.J., Sterling L.J., Marcucci G., Carroll A.J., Bloomfield C.D. 2013. New recurrent balanced translocations in acute myeloid leukemia and myelodysplastic syndromes: cancer and leukemia group B 8461, Genes, Chromosomes and Cancer 52(4), 385-401.

[2] Shaffer L.G. 2013. Microarray - Based Cytogenetics in: S.L. Gersen, M.B. Keagle (Eds.) The Principles of Clinical Cytogenetics, Springer Science+Business Media, New York.

[3] Yasar D., Karadogan I., Alanoglu G., Akkaya B., Luleci G., Salim O., Timuragaoglu A., Toruner G.A., Berker-Karauzum S. 2010. Array comparative genomic hybridization analysis of adult acute leukemia patients, Cancer Genetics and Cytogenetics, 197(2), 122-129.

[4] Boros J., O'Donnell A., Donaldson I.J., Kasza A., Zeef L., Sharrocks A.D. 2009. Overlapping promoter targeting by Elk-1 and other divergent ETS-domain transcription factor family members, Nucleic Acids Research, 37(22), 73687380 .

[5] Boros J., Donaldson I.J., O'Donnell A., Odrowaz Z.A., Zeef L., Lupien M., Meyer C.A., Liu X.S., Brown M., Sharrocks A.D. 2009. Elucidation of the ELK1 target gene network reveals a role in the coordinate regulation of core components of the gene regulation machinery, Genome Research, 19(11), 1963-1973.

[6] Cohen-Armon M. 2007. PARP-1 activation in the ERK signaling pathway, TRENDS in Pharmacological Sciences, 28(11), 556-560.

[7] Posern G., Treisman R. 2006. Actin' together: serum response factor, its cofactors and the link to signal transduction, Trends in Cell Biology, 16(11), 588-96.

[8] Schmeier S., MacPherson C.R., Essack M., Kaur M., Schaefer U., Suzuki H., Hayashizaki Y., Bajic V.B. 2009. Deciphering the transcriptional circuitry of microRNA genes expressed during human monocytic differentiation, BMC Genomics 10, 595.

[9] Wagner E.F., Nebreda A.R. 2009. Signal integration by JNK and p38 MAPK pathways in cancer development, Nature Reviews Cancer, 9(8), 537-49.

[10] McCormick F. 2011. Cancer therapy based on oncogene addiction, Journal of Surgical Oncology, 103(6), 464-7.

[11] Zhang R., Kim Y.M., Lu X., Wang X., Pang H., Li Y., Li S., Lee J.Y. 2011. Characterization of a novel 
$\mathrm{t}(2 ; 5 ; 11)$ in a patient with concurrent AML and CLL: a case report and literature review, Cancer Genetics 204(6), 328-33.

[12] Maicas M., Vazquez I., Vicente C., Garcia-Sanchez M.A., Marcotegui N., Urquiza L., Calasanz M.J., Odero M.D. 2013. Functional characterization of the promoter region of the human EVI1 gene in acute myeloid leukemia: RUNX1 and ELK1 directly regulate its transcription, Oncogene, 32(16), 2069-78.

[13] Gade P., Roy S.K., Li H., Nallar S.C., Kalvakolanu D.V. 2008. Critical role for transcription factor C/EBP-beta in regulating the expression of death-associated protein kinase 1, Molecular and Cellular Biology, 28(8), 2528-2548.

[14] Uehata T., Akira S. 2013. mRNA degradation by the endoribonuclease Regnase1/ZC3H12a/MCPIP-1, Biochimica et Biophysica Acta 1829(6-7), 708-713.

[15] Liang J., Saad Y., Lei T., Wang J., Qi D., Yang Q., Kolattukudy P.E., Fu M. 2010. MCP-induced protein 1 deubiquitinates TRAF proteins and negatively regulates JNK and NF-kappaB signaling, The Journal of Experimental Medicine, 207(13), 2959-2973.

[16] Cifuentes R.A., Cruz-Tapias P., Rojas-Villarraga A., Anaya J.M. 2010. ZC3H12A (MCPIP1): molecular characteristics and clinical implications, Clinica Chimica Acta 411(23-24), 1862-1868.

[17] Kasza A., Wyrzykowska P., Horwacik I., Tymoszuk P., Mizgalska D., Palmer K., Rokita H., Sharrocks A.D., Jura J. 2010. Transcription factors Elk-1 and SRF are engaged in IL1dependent regulation of ZC3H12A expression, BMC Molecular Biology, 11, 14.

[18] Townsend K.J., Zhou P., Qian L., Bieszczad C.K., Lowrey C.H., Yen A., Craig R.W. 1999. Regulation of MCL1 through a serum response factor/Elk-1mediated mechanism links expression of a viability-promoting member of the BCL2 family to the induction of hematopoietic cell differentiation, The Journal of Biological Chemistry, 274(3), 1801-1813.

[19] Schimmer A.D., Hedley D.W., Penn L.Z., Minden M.D. 2001. Receptor- and mitochondrialmediated apoptosis in acute leukemia: a translational view, Blood 98(13), 3541-3553.

[20] Shih L.Y., Fu J.F., Shurtleff S.A., Morris S.W., Downing J.R. 2001. Lack of BCL10 mutations in multiple myeloma and plasma cell leukemia, Genes Chromosomes Cancer, 30(4), 402-406.

[21] VanGuilder H.D., Vrana K.E., Freeman W.M. 2008. Twenty-five years of quantitative PCR for gene expression analysis, Biotechniques, 44(5), 619-626.

[22] Sharrocks A.D. 2002. Complexities in ETSdomain transcription factor function and regulation: lessons from the TCF (ternary complex factor) subfamily. The Colworth Medal Lecture, Biochemical Society Transactions, 30(2), 1-9.

[23] Eilersi, P.H., de Menezes R. X. 2005. Quantile smoothing of array CGH data, Bioinformatics 21(7), 1146-1153. 